19.Ничкало, Н. Г. Методичні проблеми безперервної професійної освіти / Н. Г. Ничкало // Психологічні проблеми безперервної професійної освіти : наук.- метод. зб. / гол. ред. І. А. Зязюн. - К. : Віпол, 1994. - С. 22-26.

20. Петров, А. Профессиональная компетентность : понятийно-терминологические проблемы / А. Петров // Alma mater. - 2004. - № 10. - С. 6-10.

21. Плужник, И. Л. Формирование межкультурной коммуникативной компетенции студентов гуманитарного профиля в процессе профессиональной подготовки : дис. ... канд. пед. наук : 13.00.01 / Плужник Ирина Ленаровна. - Тюмень, 2003. $-228 \mathrm{c}$.

22. Полонский, В. М. Словарь по образованию и педагогике / В. М. Полонский. М. : Высшая школа, 2004. - 512 с.

23. Радченко, А. Є. Моніторинг професійної педагогічної компетентності вчителя / А. С. Радченко // Управління школою. - 2005. - № 35-36. - С. 24-58.

24. Раченко, И. К. Как осуществить принцип стимулирования и перспективности в процессе организации педагогического труда / И. К. Раченко. - Пятигорск : [Б. и.], 1978. - 22 с.

25. Словник-довідник з професійної педагогіки / [авт.-упоряд. Семенова А. В.]. Одеса : Пальміра, 2006. - 272 с.

26. Український радянський енциклопедичний словник : в 3 т. / [авт.-уклад. Бабичев Ф. С.] - К. : Гол. ред. УРЕ, 1987. - Т. 3. - 736 с.

27. Хатунцева, С. М. Педагогічні умови адаптації викладача-початківця до професійно-педагогічної діяльності у вищому навчальному закладі : дис. ... канд. пед. наук : 13.00.04 / Хатунцева Світлана Миколаївна. - Х., 2004. - С. 9798.

Стаття надійшла 12.04.2016 року

УДК 372.315:808.5:811.161.2

Лариса Сауляк

(Умань, Україна)

\title{
ЛІНГВІСТИЧНІ ОСНОВИ ТА ПСИХОЛІНГВІСТИЧНІ ЧИННИКИ НАВЧАННЯ РИТОРИКИ УЧНІВ СТАРШИХ КЛАСІВ ПРОФІЛЬНОЇ ШКОЛИ
}

Засвоєння украӥнської мови вимагає від людини вмінь оцінювати ї̈ виражальні засоби $і$ користуватися ними в усному ц̆ писемному мовленні. Риторизація навчального процесу повинна йти від мовних одиниць до їх ролі в тексті, від спостереження над текстами-зразками до створення власного тексту. Уведення активних форм навчальної комунікації підвищує рівень мотивації мовленнєвої поведінки учнів.

Ключові слова: риторика, комунікативна підготовка, оратор, мовещь, мовна особистість,лінгвістичні основи, риторичний текст, культура мовлення.

Сауляк Л. Лингвистические основы и психолингвистические факторы обучения риторики учащихся старших классов профильной школь. 
Усвоения украинского языка требует от человека умения оченивать его выразительные средства и пользоваться ими в устной и письменной речи. Риторизация учебного процесса должна идти от языковых единиц к их роли в тексте, от наблюдения над текстами-образиами для создания собственного текста. Введение активных форм учебной коммуникации повымает уровень мотивации речевого поведения учащихся.

Ключевые слова: риторика, коммуникативная подготовка, оратор, говорящий, языковая личность, лингвистические основы, риторический текст, культура речи.

Saulyak L. Linguistic basis and psycholinguistic factors training rhetoric school students of specialized schools.

The acquisition of Ukrainian language requires human skills to evaluate its means of expression and to use them orally and in writing. Rytoryzatsiya educational process should go on linguistic units to their role in the text of observations on the texts-samples to create your own text. The introduction of active forms of academic communication increases motivation speech behavior of students.

Keywords: rhetoric, communication training, speaker, speaker, language identity, linguistic basis, rhetorical text of speech.

Методика навчання риторики учнів старших класів профільної школи передбачає обов'язкове врахування їхніх вікових, психологічних особливостей і механізмів мовлення. Формування риторичної компетенції школярів старшої школи не може здійснюватися без аналізу психологічних засад, оскільки вся діяльність людини формується на психологічній основі.

Нині риторика не належить до переліку обов'язкових шкільних дисциплін, тому іï розглядають переважно в площині мовної освіти. У межах чинних програм з української мови виокремлено незначну кількість годин у старших класах для засвоєння риторичних відомостей, проте їх недостатньо для того, щоб сформувати високий рівень комунікативної культури учнів.

Різні аспекти вдосконалення комунікативної підготовки учнів вивчали 3. Бакум, Є. Голобородько, Н. Голуб, О. Горошкіна, С. Караман, Л. Мамчур, А. Нікітіна, С. Омельчук, М. Пентилюк, Л. Попова, Г. Шелехова, В.Шляхова та ін. Теоретичні засади навчання риторики розроблено в працях В. Аннушкіна, М. Кохтєва, 3. Курцевої, Т. Ладиженської, Л. Мацько, А. Михальської, С. Мінєєвої, В. Нищети, Г. Сагач, Л. Синельникової, Й. Стерніна, Л. Туміної та ін. У дисертаційних роботах цю проблему досліджували Н. Голуб, Л. Горобець, А. Курінна, А. Первушина та ін. Науковці дійшли висновку, що риторика стимулює мовлення учнів, розвиває їхні комунікативні й розумові здібності; вивчення риторичних відомостей на уроках української мови сприяє формуванню мовленнєвої креативності, культури спілкування учнів. Культура спілкування грунтується на риторичних знаннях і риторичних 
уміннях, що формуються як у процесі опанування відповідних тем, так і в процесі використання цих знань і вмінь у реальній комунікативній діяльності.

Загальною умовою якісної мовної підготовки учнів старших класів має стати опора на теорію мовленнєвої діяльності (О. Леонтьєв) та психологічну теорію діяльності (Л. Виготський, О. Леонтьєв). Урахування вчителем цих закономірностей дозволить підвищити мотивацію навчальної діяльності, ефективно використати й активізувати зв'язок мовлення та мислення.

Сучасні дослідники одностайні в тому, що слід звернути увагу на комунікативні характеристики мовлення оратора, тобто на ті ознаки мовлення, якими має володіти той, хто виступає публічно. О. Юніна i Г. Сагач одними 3 найбільш актуальних визначають такі комунікативні характеристики мовлення оратора: правильність (володіння нормами літературної мови); виразність (комунікативна якість мовлення, завдяки якій здійснюється вплив на емоції та почуття аудиторії); ясність (якість мови, що забезпечує адекватне розуміння сказаного); точність (комунікативна якість мови, яка виявляється у використанні слів у повному співвідношенні 3 ii значенням); стислість; доречність (співвідношення слів і виразів, цілей і умов спілкування, тієї чи іншої аудиторіï) [27].

Провідною комунікативною ознакою мовлення $\epsilon$ правильність, що забезпечується досконалим володінням нормами літературної мови. Правильне мовлення передбачає вміння відібрати в конкретній ситуації найкращий стилістично виправданий варіант; доречно обгрунтувати застосування стилістичних норм відповідно до ситуації спілкування; будувати усні й писемні висловлювання. Отже, правильність передбачає дотримання орфоепічних, лексичних, граматичних, стилістичних, правописних норм [10, с. 33].

3 правильністю і нормативністю тісно пов'язана чистота мовлення, що зумовлює доречне застосування канцеляризмів i професіоналізмів, іншомовних слів і термінів. Усне мовлення передбачає не лише засвоєння норм, а й знання їх можливих соціальних функцій, тобто вміння точно відібрати таку одиницю, яка забезпечить досягнення мети. Точність мовлення - одна 3 його найважливіших ознак, що характеризує передусім зміст висловлювання. Це вживання точних значень слів, словосполучень, речень та вміння виражати думки так, щоб вони однозначно були сприйняті адресатом мовлення. Отже, точність мовлення залежить від сформованості вмінь мовця добирати такі слова, які повністю співвідносяться $з$ предметами, явищами, діями, що їх називають. Точність слововживання залежить від того, наскільки мовець володіє інформацією про предмет розмови, наскільки він ерудований, уміє логічно мислити, 
знає норми української літературної мови [10, с. 33-34]. Точність мовлення забезпечується не кількістю слів, а доступністю їх, недвозначністю. Можна вважати, що точність мовлення - це чемність, толерантність, мовна етика в усіх сферах спілкування [10, с. 34].

Змістовність мовлення, відображаючи зв'язок мислення й мовлення, передбачає необхідний ступінь лаконізму, відсутність порожніх фраз, багатослів'я. Багато спільного з точністю та змістовністю має логічність мовлення, яка теж характеризує зміст висловлювання й забезпечує його смислову послідовність. Крім того, логічність передбачає вміння чітко і послідовно мислити; дотримуватися логіки викладу; ураховувати мовленнєву ситуацію. Логічним називають мовлення, яке забезпечує смислові зв'язки. Дотримання логіки викладу позитивно впливає на ефективність спілкування [10, с. 34-35].

Багатство й різноманітність мовлення значною мірою залежить від того, наскільки мовець усвідомлює, у чому полягає самобутність рідної мови, іiї багатство. Серед інших складників гарної промови, дискусії, полеміки називають оригінальність, виразність, яскравість і образність [10, c. 35].

Промова в риториці - це цілісне утворення, побудоване за певними правилами і має цілеспрямований характер [3, с. 18]. Значення промови в риториці висвітлює А. Михальська, яка стверджує, що гарна промова «це промова розумна», однак не просто розумна, а «спрямована до істини i прекрасна своєю структурою й логікою, своєю впорядкованістю», «промова не нейтральна стосовно моралі, тобто добра і правдива» [18].

Оригінальність промови, на думку 3. Куньч, - це властивість публічного виступу, що полягає в самобутності їі побудови, використанні риторичних засобів, у неповторній манері поведінки оратора тощо. Оригінальність - важлива риса творчості оратора. Вона полягає у сміливості думки і схожості бачення життя, у новаторстві, в умінні серед бурхливого потоку явищ дійсності і подій підмітити і яскраво змалювати ніким раніше не помічені, але важливі факти, показати їх у новому, цікавому аспекті [11, с. 179].

Яскравість промови значною мірою виявляється в яскравості тону, інтенсивності забарвлення. Яскрава промова вражає своєю переконливістю, свіжістю, виразністю.

Образність у лінгвістичній науці розуміють як передачу «загального поняття через конкретний словесний образ», що означає «використання слів у таких сполученнях, які дають можливість посилити лексичне значення додатковими емоційно-експресивними та оцінними відтінками» $[19$, с. 212$]$.

Отже, оригінальність, виразність, яскравість і образність промови $є$

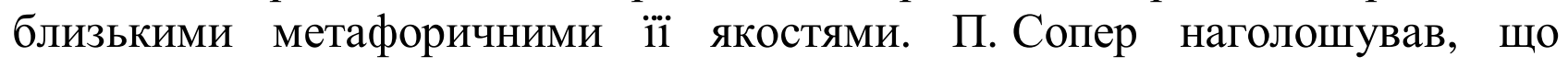


початківець має досягти: а) граматичної правильності, б) точності, в) доречності, г) економічності, г) оригінальності мови. Названі ознаки надають мовленню прямолінійного, ясного, сильного i невимушеного характеру [23, с. 303]. Це зумовлює особливу увагу вчителя-словесника на формування комунікативних якостей мовлення учнів, насамперед правильності, багатства, точності, доречності, економічності, оригінальності.

Як слушно зазначає Н. Голуб, риторику вважають наукою «текстотворчою», тому для процесу іiі навчання велике значення має поняття тексту, оскільки він становить основу виступу [5, с. 160]. Текст називають «універсальною i за багатьма показниками унікальною категорією мови», оскільки загальне поняття тексту охоплює собою всі наявні в цивілізації типи інформації, або іншими словами - уся наявна інформація надходить до мовця в різних типах і видах текстів [16, с. 13].

Різноманітність підходів до тлумачення тексту, на думку Ф. Бацевича, зумовлена багатьма причинами, «передусім важливістю цього поняття для людини, його складністю, а також багатовіковою традицією вивчення його в різних сферах знань» [2]. Учений визначає текст як результат спілкування (інтеракції та трансакції), його структурну мовну складову й одночасно кінцеву реалізацію.

Одним з основних засобів навчання риторики є риторичний текст. На думку С. Мінєєвої, цей текст має низку параметрів: авторство, адресність; як результат відносин між автором і адресатом: діалогічність, цілісність, зв’язність, впливовість. Він обслуговує певну риторичну ситуацію, що може відбиватися в тексті як ситуативність. До параметрів риторичного тексту належать також жанровість, аргументованість [17]. Таким чином риторичний текст - індивідуальне явище, створене мовцем 3 певною метою в конкретній ситуації.

В окремих текстах художньої літератури індивідуальність мовця виявляється суттєво, в науковому мовленні майже непомітна, а в ділових паперах зовсім відсутня. Семантичні, граматичні, композиційні характеристики тексту тісно пов'язані 3 його особливостями, зокрема 3 функціонально-стильовим призначенням, використанням мовних засобів, логікоструктурованою завершеністю. До основних ознак тексту належить функціонально-стильова орієнтація, що відзначається своєрідними стилістичними якостями, індивідуальністю автора, ідейним задумом тощо.

Саме тому, на думку О. Горошкіної, яскравою ознакою сучасного уроку української мови є широке й різноманітне використання текстового матеріалу - засобу навчання, що має значний дидактичний потенціал [6]. Останнім часом робота з текстом активізується, оскільки, за влучним висловом С. Єрмоленко, сьогодні ми переживаємо кризу доброго слова, на якому має виховуватися мовний смак читача [7, с. 11]. Прагнення вчителя 
до того, щоб на уроках української мови звучало зразкове мовлення, виражається в ретельному доборі дидактичного матеріалу, що, як свідчить практика, найчастіше являє собою невеликі уривки художніх творів. Це зумовлює широке використання текстового матеріалу у процесі опанування риторичних відомостей.

Щоб промова була успішною (ефективною), оратор має враховувати особливості аудиторії, перед якою він виступає. По-перше, необхідно налагодити зоровий контакт $з$ аудиторією. Не можна говорити в простір. Бесіда 3 реальними людьми в аудиторії робить мову більш виразною, а отже, цікавою і легко сприйманою. Уміння правильно спрямувати погляд - важливе вміння оратора. Не слід дивитися убік, у підлогу, собі під ноги, на стелю, у простір, на одного з присутніх у перших рядах. Мовець у подібних ситуаціях не може стежити за реакцією слухачів, не має зв' язку 3 ними, увага слухачів розсіюється, оратор не викликає інтересу. Рекомендується дивитися на слухачів, переводячи погляд 3 одного на іншого (але щоб очі «не бігали»), щоб відчути контакт зі слухачами. Подруге, впевнена поведінка оратора, твердість i рішучість у голосі, внутрішня гідність - це всіх змушує прислухатися до нього, впливає на аудиторію психологічно. Ні в кого не повинно бути сумніву, що оратор звичайна людина, що він може боятися, переживати, хвилюватися. Потретє, зовнішній вигляд оратора (адже слухач - це ще і глядач, він оцінює усе до дрібниць - костюм, зачіску, жести, міміку, позу), погляд не повинен бути порожній, відвернений, відсутній, поза - картинною, костюм i зачіска - неохайними. Таким чином, налагодження контакту з аудиторією - необхідна умова для передачі інформації.

Сформувати в старшокласників високу культуру мовлення неможливо без дотримання мовленнєвого етикету, що полягає в умінні уважно слухати співрозмовників, нікого не перериваючи, тактовно долучатися до розмови, доречно і зрозуміло висловлюватися, говорити толерантно, $з$ повагою, використовуючи гречні слова. Тому в процесі колективного обговорення певного питання, коли виникає полеміка, в першу чергу вчителеві варто з повагою ставитися до особистісного вияву учня. Своє мовлення варто супроводжувати словами: перепрошую, слушна думка, без сумніву, ти маєщ рацію, дочүільно було б..,, на мій погляд..., дякую за увагу, дякую за питання. Звідси, коли педагог навчатиме учнів дотримуватись цих етикетних норм у спілкуванні, вони не сприйматимуться ними як нав'язування чогось чужого, а як щось цілком природне. Упровадження етикетних відомостей стає імперативом у навчанні мови.

Завдання вчителя-словесника полягає у формуванні особистості, здатної до спілкування в різних життєвих ситуаціях, особистості, яка має тверду орієнтованість у навчанні. Отже, нинішнім учням, а завтрашнім 
фахівцям мова потрібна не як сукупність правил, а як засіб самоформування й самовираження особистості. На нашу думку, формуючи зміст предмета, необхідно виходити з принципу врахування комунікативних потреб учнів для майбутнього професійного спілкування. Вони повинні досконало оволодіти різноманітними видами мовленнєвої діяльності, уміти кваліфіковано вести бесіду, відчувати себе впевнено й комфортно в будь-яких ситуаціях.

Для словесників особливо важливим $є$ те, що риторика відкриває можливості нового погляду на системні особливості мови, іiі виражальні засоби, сприяє формуванню й вираженню думки, «озброює учнів знаннями й навичками активного мовного впливу, знайомить хоч би 3 основними правилами мовної діяльності різних видів» [22].

Уміння спілкуватися в різних ситуаціях із дотриманням установлених норм $є$ однією 3 найголовніших соціальних вимог, що висуваються до юнацтва. Ефективність мовленнєвого спілкування багато в чому залежить від вікових, індивідуальних особливостей людини, яка вступає в контакт 3 іншими, особливостей особистості. Ще Ф. де Соссюр розглядав мову як знакову систему, що виникає й використовується заради спілкування та в ситуаціях спілкування, $\epsilon$ його основним засобом, тобто виконує комунікативну функцію, окрім того, вона є засобом передачі інформації від мовця до слухача [24]. А відтак мова пов'язана 3 потребами та умовами комунікації людини, становить найважливіший аспект іiі соціальної поведінки, посідає певне місце в комунікативно-пізнавальній діяльності. Немає сфери людського існування, що не стосувалася б спілкування, яке, опосередковане знаками, виступає у вигляді комунікативної активності 3 власною стратегією реалізації певних комунікативно-пізнавальних завдань, а саме: привернути увагу співрозмовника, зорієнтувати його в меті та умовах спілкування, організувати смислове сприйняття співрозмовником інформації; запевнити співрозмовника, викликати його співчуття, підтримати його точку зору, тобто вплинути в процесі спілкування на іншого (інших) задля зміни його (їхньої) поведінки [13, с. 33].

Сьогодні старшокласники особливо прагнуть до самовираження, до можливості висловлювати й відстоювати свої погляди й переконання, набуває актуальності комунікативна спрямованість навчання і створення сприятливого для спілкування психологічного клімату. Тому завдання вчителя полягає в тому, щоб дібрати для уроків риторики матеріал, який би спонукав до роздумів, стимулював обмін думок. У старшому шкільному віці не тільки збільшується словниковий запас, а й набувається важлива навичка оперування словом - це шлях до масової словесної творчості, типової для підлітків, який психологи називають однаковою мірою і псуванням мови, і ії̈ збагаченням [1, с. 496]. 
Дослідження психологів і педагогів (Д. Ельконіна, Т. Ладиженської, Ю. Рождественського та ін.) показують, що робота над мовленням учнів на уроках вивчення риторики в 10-11 класах більш ефективна, якщо вчитель створює безпосередні мовленнєві ситуації, у яких учні можуть застосовувати і відпрацьовувати вивчений теоретичний матеріал. Поява i розвиток у цьому віці таких мовленнєвих функцій, як регуляція, саморегуляція, допоможуть вихованню активної, комунікабельної особистості $[26 ; 12 ; 20]$.

Дослідження психологів (Л. Виготський, М. Жинкін, О. Леонтьєв) свідчать, що мовленнєвий процес під час вивчення риторики створюється за такою схемою:

1) спонукання (наявність подразника, усвідомлення мотиву говоріння);

2) створення загального значеннєвого зразка, тобто задуму висловлювання, вираженого особливим кодом внутрішнього мовлення, добору слів, перехід коду на мовленнєві одиниці);

3) зовнішня реалізація, тобто мовне оформлення загального смислу висловлювання, доведеного до автоматизму (у тому числі вимова, інтонування, оперування словами, реченнями тощо);

4) слуховий контроль висловлювання [4; 8; 14].

Проаналізувавши наукові праці відомих психологів, психолінгвістів, можна дійти висновку, що формування риторичної компетентності учнів залежить від багатьох чинників, зокрема врахування вікових особливостей, сформованості аудіативних умінь, а також умінь читати, сприймати, відтворювати почуте висловлювання й породжувати у свідомості власне та ін. Саме ці психологічні процеси допомагають учням старших класів оволодівати риторичними знаннями й використовувати їх 3 урахуванням змісту мовлення та ситуації спілкування.

Засвоєння української мови вимагає від людини вмінь оцінювати іiі виражальні засоби і користуватися ними в усному й писемному мовленні. Виразність, емоційність мови діти вчаться відчувати змалечку, однак вивчення мови допомагає їм проникнути в тонкощі смислових i стилістичних відтінків мовних одиниць. Учні повинні навчитися оцінювати їх виразність, розрізняти семантико-стилістичні особливості багатозначних слів, лексичних і граматичних синонімів, синтаксичних структур, стилістичні колорити текстів різних типів і стилів мовлення. Ця закономірність виявляється не тільки в розумінні суті виразності мови, але й засвоєнні способів вираження емоційності та експресивності в мовленні під час спілкування, в умінні виявляти виражальні можливості мовних засобів у процесі спілкування, наприклад використовуючи складні прикметники, порівняльні звороти тощо. 
Наступна закономірність засвоєння рідної мови пов'язана з розвитком мовного чуття, даром слова, володіти яким повинна кожна інтелектуально розвинена людина, мовна особистість. Ця закономірність виявляється в розмежуванні понять мова і мовлення. Адже мовлення - це вживання мови для вираження думок і почуттів. Мовне чуття розвивається iз засвоєнням мови з раннього дитинства.

Вивчення риторики в профільній школі має практичний характер. Отже, якщо ми ставимо за мету навчити старшокласників ефективного спілкування, за якого комунікант досягає своєї мети (переконати, аргументувати, заспокоїти тощо), особливо продуктивним $є$ використання методів i прийомів навчання риторики: риторичного аналізу усних i письмових відповідей, риторичних задач, риторичних ігор.

\section{СПИСОК ВИКОРИСТАНОЇ ЛІТЕРАТУРИ}

1. Абрамова, Г. С. Возрастная психология : учеб. для вузов / Г. С. Абрамова. М. : Академ. проект, 2001. - 704 с.

2. Бацевич, Ф. С. Основи комунікативної лінгвістики : підручник / Ф. С. Бацевич. - К. : Академія, 2004. - 344 с.

3. Безменова, Н. А. Очерки по теории и истории риторики / Наталья Александровна Безменова. - М. : Наука, 1991. - 215 с.

4. Выготский, Л. С. Мышление и речь: Психологические исследования / Л. С. Выготский. - М. : Лабиринт, 1996. - 416 с.

5. Голуб, Н. Б. Риторика у вищій школі : монографія / Н. Б Голуб. - Черкаси : Брама-Україна, 2008. - 400 с.

6. Горошкіна, О. М. Лінгводидактичні засади навчання української мови в старших класах природничо-математичного профілю : монографія / О. М. Горошкіна. - Луганськ : Альма-матер, 2004. - 362 с.

7. Єрмоленко, С. Я. Нариси $з$ української словесності. Стилістика та культура мови / С. Я. Єрмоленко. - К. : Довіра, 1999. - 431 с.

8. Жинкин, Н. И. Речь как проводник информации / Н. И. Жинкин. - М. : Наука, 1982. $-159 \mathrm{c}$.

9. Ипполитова, Н. А. Русский язык и культура речи : учебник / Н. А. Ипполитова, О. Ю. Князева, М. Р. Савова ; под ред. Н. А. Ипполитовой. - М. : Проспект, 2009. - 448 c.

10.Культура мовлення вчителя-словесника / уклад. : Горошкіна О. М., Нікітіна А. В., Попова Л. О. та ін. - Луганськ : СПД Рєзніков В. С., 2007. $112 \mathrm{c}$.

11. Куньч, 3. Риторичний словник / 3. Куньч. - К. : Рідна мова, 1997. - 342 с.

12. Ладыженская, Т. А. Устная речь как средство и предмет обучения / Т. А. Ладыженская. - 2-е изд., перераб. - М. : Флинта Наука, 1998. - 136 с.

13. Леонтьев, А. А. Внеязыковая обусловленность речевого акта и некоторые вопросы обучения иностранному языку / А. А. Леонтьев // Иностр. яз. в шк. 1968. - № 2. - C. 29-35. 
14. Леонтьев, А. А. Язык и речевая деятельность в общей и педагогической психологии : избр. психол. тр. / Алексей Алексеевич Леонтьев. - М. : МПСИ, 2004. $-535 \mathrm{c}$.

15. Луценко, В. I. Методика вивчення повнозначних частин мови на функціонально-стилістичних засадах в основній школі : дис. ... канд. пед. наук : 13.00.02 / Луценко Валентина Іванівна. - Херсон, 2009. - 241 с.

16. Матвеева, Т. В. Функциональные стили в аспекте текстовых категорий / Тамара Вячеславовна Матвеева. - Свердловск : Урал. ун-т, 1990. - 624 с.

17. Минеева, С. А. Цицерон : хрестоматия по риторике: для старшеклассников школ, гимназий, лицеев, колледжей / С. А. Минеева. - Пермь : ЗУУНЦ, 1992. $104 \mathrm{c}$.

18. Михальская, А. К. Русский Сократ: лекции по сравнительно-исторической риторике : учеб. пособие для студентов гуманит. фак-тов / Анна Константиновна Михальская. - М. : Akademia, 1996. - 192 с.

19. Пономарів, О. Д. Стилістика сучасної української мови : підручник / О. Д. Пономарів. - К. : Либідь, 1993. - 248 с.

20. Рождественский, Ю. В. Теория риторики / Юрий Владимирович Рождественский. - М. : Добросвет, 1997. - 600 с.

21. Селіванова, О. О. Сучасна лінгвістика: напрями та проблеми : підручник / Олена Олександрівна Селіванова. - Полтава : Довкілля-К, 2008. - 712 с.

22. Синельникова, Л. Н. Риторика как научная и учебная дисциплина : пособие для учителей, студентов, учащихся шк. и гимназий / Л. Н. Синельникова, А. Г. Лапотько. - Луганск : Ред.-издат. отдел облуправления по печати, 1996. $89 \mathrm{c}$.

23. Сопер, П. Основы искусства речи : пер. с англ. / Сопер Поль. - 2-е испр. изд. М. : Прогресс-Академия, 1992. - 416 с.

24. Соссюр, Ф. де. Курс загальної лінгвістики / Ф. де Соссюр. - К. : Основи, 1998. $324 \mathrm{c}$.

25. Степанов, О. М. Основи психології і педагогіки : навч. посіб. / О. М. Степанов, М. М. Фібула. - К. : Академвидав, 2005. - 520 с.

26. Эльконин, Д. Б. К проблеме периодизации психического развития в детском возрасте / Д. Б. Эльконин // Вопросы психологии. - 1971. - № 4. - С. 17-19.

27. Юнина, Е. А. Общая риторика: (Современная интерпретация) / Е. А. Юнина, Г. М. Сагач. - Пермь : ЗУУНЦ, 1992. - 195 с. 